African Crop Science Journal by African Crop Science Society is licensed under a Creative Commons Attribution 3.0 Uganda License. Based on a work at www.ajol.info/ and www.bioline.org.br/cs DOI: https://dx.doi.org/10.4314/acsj.v27i4.3

\title{
EARLY SELECTION FOR YIELD IN ROBUSTA COFFEE BASED ON JUVENILE GROWTH TRAITS
}

\author{
A. AKPERTEY, E. ANIM-KWAPONG ${ }^{1}$ and A. OFORI \\ Cocoa Research Institute of Ghana, P. O. Box 8, New Tafo-Akim, Ghana \\ ${ }^{1}$ Seed Production Division, Ghana Cocoa Board, P. O. Box 3197, Accra, Ghana \\ Corresponding author: aakpertey@yahoo.com
}

(Received 30 June 2019; accepted 28 October 2019)

\begin{abstract}
Variety development, particularly for tree crops is a long-term exercise requiring significant resource investments, over many years of evaluation. Identification of traits at early growth stages that are predictive of future performance would facilitate the breeding process. The objective of this study was to assess the value of juvenile trunk cross-sectional area (TCSA) and number of laterals for selecting high-yielding Robusta coffee (Coffea canephora) genotypes, early in a breeding programme. Seventy-two Robusta coffee clones developed by either ortet selection, from previous progeny trials/ clonal trials carried out at the Cocoa Research Institute of Ghana (CRIG), were planted in 2011 in a randomised complete-block design with five replications, at CRIG's experimental fields. Juvenile TCSA and number of laterals were effective predictors of yield. Genotypes that combined small TCSA and less number of laterals at the juvenile growth phase had the lowest cumulative yields, and vice versa. TCSA was significantly associated with yearly yields $(2015: \mathrm{r}=0.49, \mathrm{P}<0.001 ; 2017: \mathrm{r}=0.35, \mathrm{P}<0.001)$ and cumulative yield $(\mathrm{r}=0.41, \mathrm{P}<0.001)$. Similarly, a significant $(\mathrm{P}<0.001)$ correlation was observed between juvenile number of laterals and yearly yields $(2015: \mathrm{r}=0.58,2016: \mathrm{r}=0.24 ; 2017: \mathrm{r}=0.48)$, and cumulative yield $(r=0.57, P<0.001)$. A selection index that combines large juvenile TCSA and many number of laterals has the potential of identifying productive genotypes early in a Robusta coffee breeding programme.
\end{abstract}

Key Words: Coffea canephora, number of laterals, trunk cross-sectional area

\section{RÉSUMÉ}

Le développement des variétés, en particulier pour les cultures arboricoles, est un exercice à long terme qui nécessite des ressources importantes investissements, au cours de nombreuses années d'évaluation. Identification des traits aux premiers stades de croissance qui sont une prévision des performances futures faciliterait le processus de sélection. L'objectif de cette étude était d'évaluer la valeur de la section transversale du tronc juvénile (TCSA) et le nombre de traversées pour sélection de génotypes de café Robusta (Coffea canephora) à haut rendement, au début d'un programme de sélection. Soixante-douze clones de café Robusta ont été mis au point soit par sélection, soit à partir 
d'essais antérieurs sur la descendance / essais clonaux réalisés à l'Institut de recherche sur le cacao du Ghana (CRIG) ont été plantés en 2011 dans un conception de blocs complets randomisés avec cinq répétitions, sur les champs expérimentaux de CRIG. TCSA juvénile et le nombre de latéraux étaient des prédicteurs efficaces du rendement. Des génotypes combinant de petites TCSA et un nombre moins élevé de plantes latérales à la phase de croissance juvénile présentait les rendements cumulatifs les plus bas, et inversement. Le TCSA était associé de manière significative aux rendements annuels (2015: $\mathrm{r}=0,49, \mathrm{P}<0,001 ; 2017: \mathrm{r}=0,35, \mathrm{P}<0,001)$ et rendement cumulé $(\mathrm{r}=0,41, \mathrm{P}<0,001)$. De même, une corrélation significative $(\mathrm{P}<0,001)$ a été observée entre le nombre de latérales juvéniles et les rendements annuels (2015: $r=0,58,2016: r=0,24 ; 2017: r=0,48)$, et rendement cumulé $(r=0,57, P<0,001)$. Un index de sélection associant une grande TCSA juvénile et de nombreuses nombre de produits latéraux a le potentiel d'identifier des génotypes productifs tôt dans un café Robusta programme d'élevage.

Mots Clés: Coffea canephora, nombre de latéraux, section transversale du tronc

\section{INTRODUCTION}

The genus Coffea of the family Rubiaceae consists of 124 species (Davis, 2011), of which two species, Coffea arabica L. and Coffea canephora Pierre ex. A. Froehner make up the bulk of commercially traded coffee. Selection for high berry yield is a key objective in many Robusta coffee (Coffea canephora) breeding programmes globally. However, yield is a quantitative trait under the control of many genes that direct selection per se may not be efficient in its improvement. Therefore, indirect selection through traits that have relatively higher heritability and correlate strongly with yield, may be more efficient in the genetic improvement of this trait (Falconer, 1998).

In Ghana, much of the yield improvement in Robusta coffee research was attributable to local germplasm collections and foreign germplasm introductions (Anim-Kwapong and Adomako, 2010) that were generally vigorous during the juvenile stages of growth, thereby making the understanding of the relationship between juvenile growth and yield very important in improving coffee productivity in the country.

One key goal of fruit tree crop breeding is to continuously develop and improve superior breeding progenies to enable genetic advancement through successive generations (Soh et al., 2003), which could be a long- term endeavor. Also, coffee, like many other perennial plant species, exhibits pronounced annual yield fluctuations which results in biennial yield cycle across several years and differences in earliness and productive longevity (Sera, 2001). This agronomic uniqueness makes breeding and improvement of $C$. canephora a difficult and slow process, requiring several years of yield data (5 to 7 years), to practice selection in a generation (Anim-Kwapong et al., 2011). To circumvent the agronomic peculiarities of the coffee crop, viz-a-viz deployment of new varieties for farmers in a timely manner, it is important to identify and adopt strategies that would speed up the breeding process.

Trunk cross-sectional area (TCSA) provides integrative information about whole tree growth and it is the commonest variable used to estimate cumulative growth over long periods in tree species (Lachenaud et al., 2007). Plant size during the juvenile growth phase may have a positive influence on vigour, overall survival and subsequent growth and development of a crop. Genotypes with high early seedling vigour are expected to establish faster, by maximising the use of available water, nutrients and solar energy. Souza et al. (2017) found a significant correlation between tree vigour and yield, and posited that vigour could be used for indirect selection for yield in a rubber tree breeding programme. In cocoa, Lachenaud and Montagnon (2002) 
studied differences in vigour of individual trees in full-sib families and observed that high coefficient of variation in tree-to-tree bean yields were related to differences in tree vigour. Ofori et al. (2014) found that more vigourous genotypes had higher survival rates than less ones under moisture stress conditions in cocoa, during field establishment. Given the importance of the relationship between vegetative vigour and productivity, a selection criterion in coffee involving vegetative growth traits during the juvenile phase of the crop would go a long way to facilitate Robusta coffee breeding efforts.

Indirect selection for yield based on early stage growth traits has been effectively applied in the improvement of olives (Moreno-Alías et al., 2010) and kola (Akpertey et al., 2017). Similarly, in Robusta coffee, selection indices for vigour, moisture stress tolerance and yield using quantitative traits (stem diameter, number of laterals, span and height) have been shown to be successful (Walyaro and Van Der Vossen, 1979; Anim-Kwapong et al., 2011). The objective of the study was to assess the value of juvenile trunk cross-sectional area (TCSA) and number of laterals for selecting precocious and high-yielding Robusta coffee genotypes in a breeding programme.

\section{MATERIALS AND METHODS}

Plant material. The study utilised 72 Robusta coffee clones, developed by either ortet selection based on yield, out-turn and plant architecture from coffee progeny trials, or from clonal trials carried out at the Cocoa Research Institute of Ghana (CRIG). From both hybrid and clonal trials, the highestyielding progenies or clonal families were identified on the basis of yield, out-turn and plant architecture.

The best plants from the best progenies or clonal families were selected and cuttings were obtained from them to generate the clones evaluated in this study. In generating the experimental materials, single-node cuttings of each clone were rooted in propagators filled with 1:1 mixture of sand and rice husk, and nursed in nursery bags for six months before they were transplanted in the field.

\section{Experimental design and field establishment. The Robusta coffee} genotypes were planted at the experimental fields of CRIG, Tafo (latitude $06^{\circ} 132 \mathrm{~N}$, longitude $0^{\circ} 222 \mathrm{~W}$ ), which is approximately 220 meters above sea level, situated in the Eastern Region of Ghana. The soil at Tafo is sandy loam, classified as Haplic Luvisol, brown to yellowish red, well drained, and developed in situ from weathered materials of hornblende granodiorite (Adu and Asiamah, 1992).

A randomised complete block design, with five replications, was used to establish sixmonth old test plants (72 genotypes) in June, 2011. For each genotype, 5 plants were planted in single rows in each replicate block, at a spacing of $2 \mathrm{~m} \times 3 \mathrm{~m}$.

Stem cuttings of Gliricidia sepium were planted between rows at a spacing of $4 \mathrm{~m} \times 6$ $\mathrm{m}$, to serve as permanent shade. Each year, the Gliricidia shade was managed by pruning to avoid over shading of the coffee plants. Pruning of the coffee plants was done by removing unwanted vegetative growth or side shoots periodically with a pair of secateurs or cutlass.

No fertilisers were applied, and weeds were removed manually by slashing the experimental field at least four times a year. The experimental field relied on natural rainfall as the source of moisture for the test plants.

Data collection and analysis. Plant height was measured when the plants were two years after planting, with a meter rule, from the soil surface to the apex of the plant. The diameter of the main stem was measured $10 \mathrm{~cm}$ above the soil surface, with electronic calipers, at yearly intervals in March, 2013 and March, 2014.

Canopy diameter, referred to as Span here forth, was taken as the width of the canopy, where tree canopy was the widest at yearly 
intervals in March, 2013 and March, 2014. The number of laterals per tree was counted in March, 2013 and March, 2014. Whenever there were multiple stems, stem diameter was calculated according to Stewart and Salazar (1992) and span was measured only on the biggest stem.

Juvenile vegetative growth data used in the analyses included the mean trait measurements collected in 2013 and 2014, whereas the yield data spanned a 3-year period (2015 to 2017). Cherry weight was recorded for three productive years (2015 to 2017). Cherry weight was transformed to clean coffee yield with a conversion factor of 0.22 (Coste, 1992). Trunk cross-sectional area (TCSA) was estimated from the stem diameter measurements as:

$\operatorname{TCSA}=\frac{\pi d^{2}}{4} ;$ where $\mathrm{d}$ is the stem diameter.

All statistical analyses were performed using the GenStat Statistical Software, version 12 (VSN International Ltd, Hemel Hempstead, UK). Analysis of variance (ANOVA) was performed following a mixed procedure (REML methods), where genotypes and replications were considered as random and fixed effects, respectively. Variance component estimates from the mixed analysis procedure (REML analysis) were used to estimate broad-sense heritability $\left(\mathrm{h}^{2}\right)$ as:

$h^{2}=\frac{\sigma^{2} g}{\sigma^{2} p}$

Where:

$\sigma_{\mathrm{g}}^{2}=$ genotypic variance and $\sigma_{\mathrm{P}}^{2}=$ phenotypic variance.

Genotypic coefficient of variation (GCV) and phenotypic coefficient of variation (PCV) were estimated following Burton (1952), viz:

$$
\begin{aligned}
& \text { GCV }=\frac{\sqrt{\sigma^{2} \mathrm{~g}}}{\mathrm{M}} \times 100 ; \text { and PCV } \\
& =\frac{\sqrt{\sigma^{2} \mathrm{p}}}{\mathrm{M}} \times 100
\end{aligned}
$$

Where: $\mathrm{M}$ is the trait mean

Best linear unbiased predictors (BLUP) for each agronomic trait assessed in the present study was obtained from the REML analysis of variance. To assess the effects of selection for yield based on juvenile TCSA, we used a $t$-test to assess the differences in yield of two sets of genotypes with contrasting mean juvenile TCSA between 2013 and 2014. For this analysis, the first set (large TCSA) consisted of the genotype with the largest mean juvenile TCSA and those with juvenile TCSA not significantly different $(\mathrm{P}>0.05)$ from this genotype, and the second set (small TCSA) consisted of the genotype with the smallest mean juvenile TCSA and all other genotypes with TCSA not significantly different $(\mathrm{P}>0.05)$ from this genotype.

Also, we used a t-test to assess differences in yield of two sets of genotypes with contrasting mean number of laterals between 2013 and 2014, to assess the effects of possible selection for yield based on number of laterals, early in a breeding programme. For this analysis, the first set (more number of laterals) comprised of the top 10 genotypes that were not significantly $(\mathrm{P}>0.05)$ different from the genotype with the highest mean number of laterals between 2013 and 2014; whereas the second set (less number of laterals) consisted of the bottom 10 genotypes that were not significantly $(\mathrm{P}>0.05)$ different from the genotype with the least number of laterals between 2013 and 2014. Spearman's Rank correlation analysis was performed to assess the association between the growth and yield traits. 


\section{RESULTS}

Genotypic performance. Significant differences $(P<0.05)$ were observed among the genotypes for all traits measured. Juvenile TCSA ranged from $6.0 \mathrm{~cm}^{2}$ in genotype M5 to $17.8 \mathrm{~cm}^{2}$ in genotype B96 (Table 1). Height ranged from $1.4 \mathrm{~m}$ in genotype M5 to $2.4 \mathrm{~m}$ in genotype K475. The number of laterals per plant, ranged from 44.5 for genotype M5 to 69.0 in genotype B96. For all the genotypes evaluated, K475 recorded the widest span of $1.8 \mathrm{~m}$, whereas genotypes H885 and 181 recorded the shortest $(1.2 \mathrm{~m})$ span.

There was a significant variation for yield in 2015 with over a five-fold difference between the least (K475) and highest-yielding (E90) genotypes, with a mean of $1.6 \mathrm{t} \mathrm{ha}^{-1}$ (Table 1). There was an improved yield pattern in 2017 with an average yield of $2.6 \mathrm{t} \mathrm{ha}^{-1}$. There was a 6-fold variation in cumulative yield (from 2015 to 2017) from $1.4 \mathrm{tha}^{-1}$ in genotype PA286 to $8.5 \mathrm{t} \mathrm{ha}^{-1}$ in genotype E139 (Table $1)$.

Based on cumulative yield grouping, we relied on the average berry yields of the highest and least-yielding Robusta coffee genotypes to study yield variation between years. A biennial bearing habit was evident in the crop (Fig. 1), as shown for other fruit tree crops such as citrus (Sposito et al., 1998), mango (Souza et al., 2004), apple (Mcartney et al., 2013), kola (Akpertey et al., 2017) and olives (Benjeddou et al., 2019). Regardless of the year of yield harvesting, the ranking of progenies for annual yields remained generally similar, with each genotype displaying a biennial yielding pattern (data not presented).

Generally, for all the genotypes assessed, a high annual yield was preceded by a low annual yield, and vice versa. Regardless of this pattern of yield variation between years, the highest-yielding genotypes $(n=4)$ were consistently higher than the least-yielding genotypes $(n=10)$, with clearly noticeable differences in 2015 and 2017 (Fig. 1).
Relationship between plant parameters. Highly significant correlations were observed between juvenile TCSA and 2015 yield $(\mathrm{r}=$ $0.49, \mathrm{P}<0.001), 2017$ yield $(\mathrm{r}=0.35, \mathrm{P}<$ $0.01)$, three-year mean yield $(\mathrm{r}=0.40, \mathrm{P}<$ $0.001)$, and cumulative yield $(r=0.41, p<$ 0.001 ) (Table 2). Similarly, the number of laterals was significantly correlated with 2015 yield $(r=0.58, P<0.001), 2017$ yield $(r=$ $0.48, \mathrm{P}<0.001)$, three-year mean yield $(\mathrm{r}=$ $0.54, \mathrm{P}<0.001)$, and cumulative yield $(\mathrm{r}=$ $0.57, \mathrm{P}<0.001$ ) (Table 2).

The 2015 yield was significantly and strongly correlated with 2017 yield $(r=0.70$, $\mathrm{P}<0.001)$, three-year mean yield $(\mathrm{r}=0.84$, $\mathrm{P}$ $<0.01)$, and cumulative yield $(\mathrm{r}=0.87, \mathrm{P}<$ 0.001 ) (Table 2). Similarly, the 2016 yield was moderately correlated with 2017 yield $(\mathrm{r}=$ $0.27, \mathrm{P}<0.05)$ and cumulative yield $(\mathrm{r}=0.29$, $\mathrm{P}<0.001)$. Also, a high and significant correlation was observed between the 2017 yield and three-year yield $(r=0.93, P<0.001)$ and cumulative yield $(\mathrm{r}=0.94, \mathrm{P}<0.001)$ (Table 2).

Variance components and genetic parameter estimates. Generally, moderate heritability estimates were observed for all traits assessed (Table 3). For all the traits, the environmental variance component estimate was larger than the genotypic variance component estimate, leading to the ratio of environmental variance to genotypic variance for all traits being positive and greater than 1 (Table 3). Broad-sense heritability estimate was moderate for TCSA $(0.31 \pm 0.09)$ and the number of laterals $(0.30 \pm 0.05)$.

There was less variability in broad-sense heritability estimates for yield traits, which ranged from $0.26 \pm 0.06$ for 2015 yield to $0.33 \pm 0.11$ for cumulative yield (Table 3 ). The estimated GCV values ranged from $9.8 \%$ for span to $80.7 \%$ for 2016 yield (Table 3). PCV, on the other hand, ranged from $19.4 \%$ for height to $146.5 \%$ for 2016 yield (Table 3 ). 
TABLE 1. Growth and yield trait measurements of 72 Robusta coffee clones evaluated for 6 years in New Tafo-Akim, Ghana

\begin{tabular}{|c|c|c|c|c|c|c|c|c|c|}
\hline Clone & $\begin{array}{l}\text { TCSA } \\
\left(\mathrm{cm}^{2}\right)\end{array}$ & $\begin{array}{l}\text { Height } \\
\text { (m) }\end{array}$ & $\begin{array}{l}\text { No. of } \\
\text { laterals }\end{array}$ & $\begin{array}{l}\text { Span } \\
(\mathrm{m})\end{array}$ & $\begin{array}{l}\text { Yld15 } \\
\left(\mathrm{t} \mathrm{ha}^{-1}\right)\end{array}$ & $\begin{array}{l}\text { Yld16 } \\
\left(\mathrm{t} \mathrm{ha}^{-1}\right)\end{array}$ & $\begin{array}{l}\text { Yld17 } \\
\left(\mathrm{t} \mathrm{ha}^{-1}\right)\end{array}$ & $\begin{array}{l}\text { AYld } \\
\left(\mathrm{t} \mathrm{ha}^{-1} \mathrm{yr}^{-1}\right)\end{array}$ & $\begin{array}{r}\text { CMYld } \\
\left(\mathrm{t} \mathrm{ha}^{-1}\right)\end{array}$ \\
\hline B96 & 17.8 & 2.2 & 69.0 & 1.6 & 3.1 & 0.2 & 4.2 & 2.5 & 7.5 \\
\hline E164 & 17.7 & 2.2 & 61.0 & 1.7 & 1.7 & 0.3 & 3.2 & 1.9 & 4.9 \\
\hline 47 & 17.0 & 2.1 & 60.1 & 1.5 & 1.6 & 0.3 & 2.2 & 1.5 & 3.8 \\
\hline E90 & 16.5 & 2.0 & 67.9 & 1.7 & 3.1 & 0.4 & 4.2 & 2.9 & 7.6 \\
\hline E138 & 16.3 & 1.9 & 63.5 & 1.6 & 2.0 & 0.4 & 3.0 & 1.9 & 5.3 \\
\hline H204 & 16.2 & 2.0 & 57.7 & 1.6 & 2.4 & 0.2 & 2.8 & 2.5 & 5.1 \\
\hline H316 & 16.1 & 2.0 & 59.2 & 1.7 & 1.3 & 0.3 & 1.9 & 1.3 & 3.1 \\
\hline E119 & 15.9 & 2.1 & 65.8 & 1.6 & 2.5 & 0.4 & 3.9 & 2.3 & 6.5 \\
\hline A129 & 15.4 & 2.2 & 64.5 & 1.6 & 1.7 & 1.0 & 3.7 & 2.1 & 6.2 \\
\hline H957 & 14.8 & 1.9 & 63.1 & 1.6 & 1.6 & 0.3 & 2.2 & 1.5 & 4.0 \\
\hline K475 & 14.6 & 2.4 & 65.4 & 1.8 & 0.6 & 0.2 & 1.9 & 1.0 & 2.5 \\
\hline B8 & 14.2 & 1.9 & 60.3 & 1.6 & 1.9 & 0.2 & 2.9 & 2.0 & 4.9 \\
\hline C180 & 14.0 & 2.0 & 49.1 & 1.4 & 1.5 & 0.2 & 2.4 & 1.6 & 3.7 \\
\hline E152 & 13.7 & 2.1 & 66.0 & 1.7 & 2.6 & 0.8 & 3.6 & 2.7 & 6.3 \\
\hline C179 & 13.7 & 1.9 & 55.0 & 1.4 & 2.4 & 0.3 & 3.3 & 2.4 & 5.8 \\
\hline $\mathrm{H} 250$ & 13.7 & 2.1 & 66.0 & 1.6 & 1.1 & 0.3 & 2.0 & 1.4 & 3.0 \\
\hline E139 & 13.5 & 2.0 & 64.7 & 1.6 & 2.8 & 1.3 & 4.5 & 2.9 & 8.5 \\
\hline E76 & 13.5 & 2.0 & 61.6 & 1.6 & 2.3 & 0.3 & 5.4 & 2.7 & 7.8 \\
\hline A213 & 13.3 & 2.0 & 51.2 & 1.5 & 1.7 & 0.3 & 2.4 & 1.6 & 4.2 \\
\hline H449 & 12.8 & 2.1 & 61.6 & 1.7 & 3.0 & 0.2 & 4.1 & 2.9 & 7.4 \\
\hline B4 & 12.7 & 1.9 & 53.9 & 1.5 & 1.6 & 0.3 & 2.4 & 1.7 & 4.0 \\
\hline H324 & 12.6 & 1.9 & 52.7 & 1.5 & 1.3 & 0.1 & 2.4 & 1.6 & 3.5 \\
\hline PB443 & 12.6 & 1.8 & 55.0 & 1.5 & 1.2 & 0.2 & 1.7 & 1.2 & 2.8 \\
\hline C134 & 12.3 & 1.9 & 52.1 & 1.5 & 1.3 & 0.2 & 2.4 & 1.5 & 3.7 \\
\hline E174 & 12.3 & 1.9 & 56.7 & 1.6 & 1.8 & 0.2 & 1.9 & 1.4 & 3.8 \\
\hline PB440 & 12.3 & 2.0 & 64.0 & 1.7 & 1.3 & 0.3 & 2.6 & 1.7 & 3.8 \\
\hline E63 & 12.2 & 1.8 & 61.7 & 1.6 & 2.0 & 0.4 & 3.6 & 2.3 & 5.9 \\
\hline 149 & 12.1 & 1.8 & 59.4 & 1.4 & 1.9 & 0.5 & 2.7 & 1.9 & 4.8 \\
\hline $\mathrm{J} 21$ & 12.1 & 2.0 & 62.6 & 1.4 & 1.7 & 0.2 & 1.5 & 1.3 & 3.2 \\
\hline H505 & 11.8 & 1.6 & 47.5 & 1.4 & 1.3 & 0.3 & 2.2 & 1.4 & 3.4 \\
\hline B178 & 11.7 & 2.1 & 53.3 & 1.4 & 2.1 & 0.3 & 3.7 & 2.3 & 6.0 \\
\hline B36B & 11.5 & 2.0 & 58.5 & 1.6 & 2.6 & 0.1 & 2.9 & 2.6 & 5.7 \\
\hline C193 & 11.4 & 1.8 & 47.3 & 1.4 & 1.2 & 0.3 & 1.5 & 1.0 & 2.5 \\
\hline H408 & 11.3 & 1.9 & 57.8 & 1.5 & 1.1 & 0.2 & 2.0 & 1.4 & 3.1 \\
\hline H116 & 11.3 & 1.9 & 54.2 & 1.4 & 1.7 & 0.2 & 2.9 & 2.0 & 4.5 \\
\hline A115 & 11.3 & 2.0 & 58.0 & 1.6 & 1.8 & 0.3 & 2.4 & 1.7 & 4.3 \\
\hline H1070 & 11.1 & 1.8 & 64.9 & 1.5 & 1.8 & 0.3 & 2.5 & 1.9 & 4.3 \\
\hline H321 & 11.0 & 1.9 & 55.3 & 1.5 & 2.1 & 0.8 & 2.8 & 2.0 & 5.5 \\
\hline H643 & 10.9 & 1.9 & 57.7 & 1.6 & 1.9 & 0.6 & 2.4 & 1.7 & 4.8 \\
\hline PB372 & 10.9 & 1.8 & 56.4 & 1.4 & 1.9 & 0.5 & 3.4 & 2.1 & 5.3 \\
\hline H497 & 10.9 & 1.8 & 60.6 & 1.5 & 1.5 & 0.3 & 4.8 & 3.1 & 6.3 \\
\hline H388 & 10.8 & 1.8 & 51.8 & 1.5 & 2.1 & 0.1 & 2.7 & 2.0 & 4.8 \\
\hline E89 & 10.7 & 1.8 & 54.9 & 1.6 & 1.9 & 0.2 & 1.8 & 1.5 & 3.7 \\
\hline
\end{tabular}


TABLE 1. Contd.

\begin{tabular}{|c|c|c|c|c|c|c|c|c|c|}
\hline Clone & $\begin{array}{l}\text { TCSA } \\
\left(\mathrm{cm}^{2}\right)\end{array}$ & $\begin{array}{l}\text { Height } \\
\text { (m) }\end{array}$ & $\begin{array}{l}\text { No. of } \\
\text { laterals }\end{array}$ & $\begin{array}{l}\text { Span } \\
(\mathrm{m})\end{array}$ & $\begin{array}{l}\text { Yld15 } \\
\left(\mathrm{t} \mathrm{ha}^{-1}\right)\end{array}$ & $\begin{array}{l}\text { Yld16 } \\
\left(\mathrm{t} \mathrm{ha}^{-1}\right)\end{array}$ & $\begin{array}{l}\text { Yld17 } \\
\left(\mathrm{t} \mathrm{ha}^{-1}\right)\end{array}$ & $\begin{array}{l}\text { AYld } \\
\left(\mathrm{t} \mathrm{ha}^{-1} \mathrm{yr}^{-1}\right)\end{array}$ & $\begin{array}{r}\text { CMYld } \\
\left(\mathrm{t} \mathrm{ha}^{-1}\right)\end{array}$ \\
\hline H898 & 10.6 & 1.8 & 55.1 & 1.5 & 1.2 & 0.3 & 2.8 & 1.7 & 3.9 \\
\hline B2 & 10.3 & 1.7 & 49.2 & 1.4 & 1.5 & 0.2 & 2.5 & 1.6 & 3.9 \\
\hline $\mathrm{H} 205$ & 10.3 & 1.6 & 51.6 & 1.4 & 1.2 & 0.1 & 2.7 & 1.5 & 3.8 \\
\hline B12 & 10.0 & 1.6 & 46.0 & 1.3 & 1.0 & 0.2 & 1.9 & 1.3 & 2.9 \\
\hline H55 & 9.9 & 1.7 & 49.1 & 1.3 & 1.4 & 0.2 & 2.0 & 1.4 & 3.5 \\
\hline 181 & 9.9 & 1.9 & 54.3 & 1.2 & 1.9 & 0.2 & 3.0 & 2.0 & 5.0 \\
\hline BC4 & 9.9 & 1.9 & 52.8 & 1.5 & 1.5 & 0.4 & 1.9 & 1.5 & 3.4 \\
\hline 197 & 9.7 & 1.9 & 59.2 & 1.4 & 1.5 & 0.3 & 2.5 & 1.6 & 3.8 \\
\hline B5 & 9.5 & 1.7 & 53.0 & 1.4 & 1.4 & 0.3 & 3.0 & 1.7 & 4.5 \\
\hline 126 & 9.5 & 1.7 & 56.8 & 1.5 & 2.2 & 0.3 & 4.0 & 2.2 & 6.6 \\
\hline B3 & 9.4 & 1.7 & 44.9 & 1.3 & 1.1 & 0.3 & 1.5 & 1.2 & 2.5 \\
\hline PA193 & 9.4 & 2.0 & 64.8 & 1.5 & 2.1 & 0.2 & 2.3 & 1.6 & 4.5 \\
\hline $\mathrm{J} 32$ & 9.3 & 1.6 & 53.2 & 1.5 & 0.9 & 0.2 & 1.4 & 1.0 & 2.4 \\
\hline B190 & 8.9 & 1.9 & 55.4 & 1.3 & 1.9 & 0.2 & 4.5 & 2.9 & 6.5 \\
\hline B7 & 8.7 & 1.7 & 44.7 & 1.4 & 1.3 & 0.2 & 1.8 & 1.2 & 2.9 \\
\hline PA35 & 8.6 & 1.8 & 53.3 & 1.4 & 1.5 & 0.2 & 1.8 & 1.5 & 3.1 \\
\hline PA413 & 8.6 & 1.8 & 49.5 & 1.4 & 1.2 & 0.4 & 2.1 & 1.3 & 3.2 \\
\hline PA286 & 8.6 & 1.6 & 50.6 & 1.3 & 0.8 & 0.3 & 0.9 & 0.6 & 1.4 \\
\hline A101 & 8.6 & 1.7 & 52.0 & 1.3 & 1.3 & 0.3 & 2.4 & 1.4 & 3.7 \\
\hline $\mathrm{H} 207$ & 8.5 & 1.7 & 50.8 & 1.4 & 1.2 & 0.3 & 3.1 & 1.6 & 4.3 \\
\hline B11 & 8.4 & 1.6 & 46.5 & 1.4 & 1.3 & 0.2 & 2.6 & 1.7 & 3.8 \\
\hline BC5 & 8.2 & 1.7 & 46.3 & 1.3 & 1.0 & 0.3 & 1.9 & 1.2 & 2.9 \\
\hline B191 & 7.7 & 1.9 & 52.1 & 1.4 & 1.2 & 0.2 & 2.1 & 1.2 & 3.3 \\
\hline $\mathrm{H} 234$ & 7.7 & 1.6 & 46.3 & 1.3 & 1.4 & 0.2 & 2.1 & 1.6 & 3.6 \\
\hline C147 & 7.4 & 1.5 & 45.7 & 1.3 & 1.2 & 0.3 & 2.0 & 1.5 & 3.3 \\
\hline H885 & 7.2 & 1.6 & 47.3 & 1.2 & 1.1 & 0.3 & 2.0 & 1.1 & 3.0 \\
\hline $\mathrm{H} 210$ & 6.9 & 1.6 & 49.1 & 1.3 & 1.4 & 0.2 & 2.3 & 1.4 & 3.6 \\
\hline $\mathrm{H} 246$ & 6.9 & 1.5 & 50.1 & 1.3 & 1.3 & 1.2 & 2.9 & 1.8 & 4.9 \\
\hline M5 & 6.0 & 1.4 & 44.5 & 1.3 & 1.1 & 0.3 & 1.5 & 1.1 & 2.5 \\
\hline $\mathrm{SED}_{\mathrm{P}<0.05}$ & 51.6 & 0.1 & 4.6 & 0.1 & 0.3 & 0.2 & 0.5 & 0.3 & 0.8 \\
\hline
\end{tabular}

TCSA = Juvenile trunk cross-sectional area; Yld15 = 2015 mean yield; Yld16 - 2016 mean yield; Yld17 = 2017 mean yield; AYld - 2015 to 2016 mean yield; CMYld = 2015 to 2017 cumulative yield; and SED $=$ standard error of difference

Yield patterns and selection based on juvenile TCSA and number of laterals. We evaluated with a t-test, the effects of selection for yield based on mean juvenile TCSA between 2013 and 2014 (Table 4). Except for selection for 2016 yield, there was a significant difference for all yield traits, where the set of genotypes with large juvenile mean TCSA (n $=10$ ) consistently out-yielded the set of genotypes with a small juvenile mean TCSA $(n=16)$. Although the differences for all yield traits were significant, the difference was more pronounced for cumulative yield, with a superior yield advantage for those genotypes 


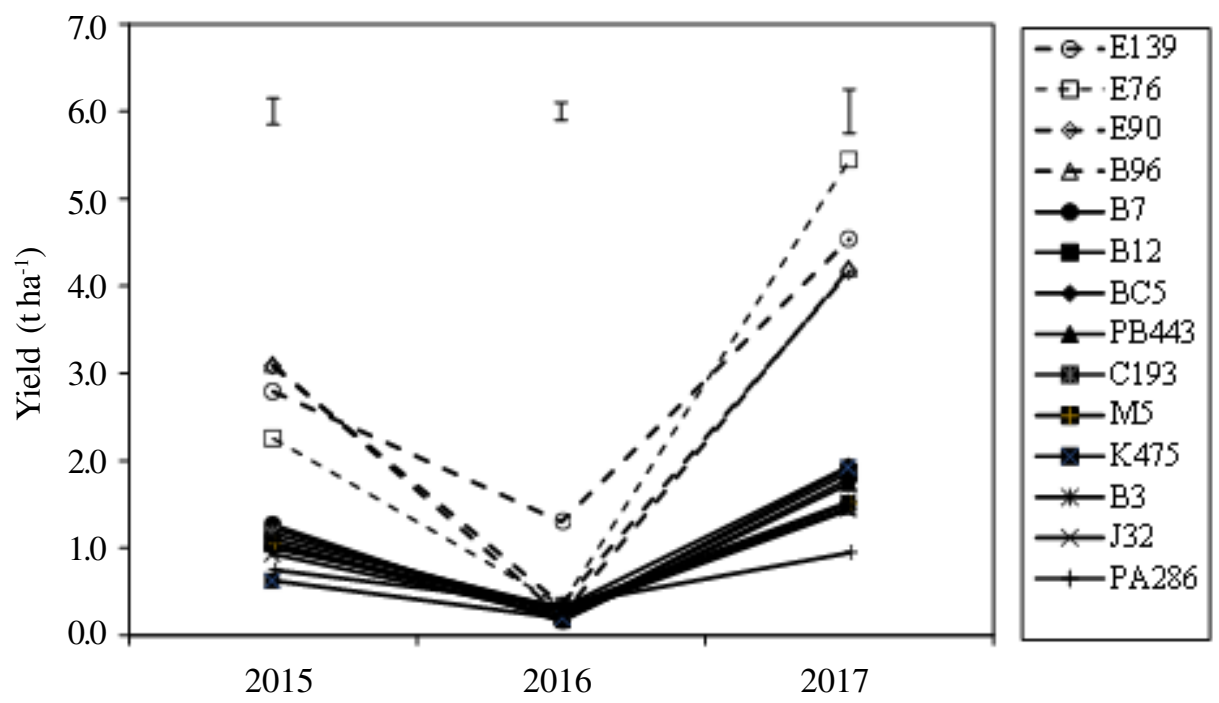

Figure 1. Pattern of mean yearly clean coffee yield performance of highest and least-yielding Robusta coffee genotypes. Grouping was based on cumulative yield from 2015 to 2017. Highest-yielding group $(\mathrm{n}=4)$ were not significantly $(\mathrm{P}>0.05)$ different from each other (broken lines; open shaped marker); least yielding group $(\mathrm{n}=10)$ were not significantly $(\mathrm{P}>0.05)$ different from each other (solid line; filled shape marker). Error bars are standard error of difference bars.

TABLE 2. Spearman's Rank correlations $(n=72)$ between TCSA and number of laterals and clean coffee yield of 72 Robusta coffee clones evaluated for 6 years in New Tafo-Akim, Ghana

\begin{tabular}{|c|c|c|c|c|c|c|}
\hline Trait & $\begin{array}{r}\text { TCSA } \\
\left(\mathrm{cm}^{2}\right)\end{array}$ & $\begin{array}{l}\text { No. of } \\
\text { laterals }\end{array}$ & $\begin{array}{l}\text { Yld15 } \\
\left(\mathrm{t} \mathrm{ha}^{-1}\right)\end{array}$ & $\begin{array}{l}\text { Yld16 } \\
\left(\mathrm{t} \mathrm{ha}^{-1}\right)\end{array}$ & $\begin{array}{l}\text { Yld17 } \\
\left(\mathrm{t} \mathrm{ha}^{-1}\right)\end{array}$ & $\begin{array}{l}\text { AYld } \\
\left(\mathrm{t} \mathrm{ha}^{-1} \mathrm{yr}^{-1}\right)\end{array}$ \\
\hline No. of laterals & $0.70 * * *$ & & & & & \\
\hline Yld15 & $0.49 * * *$ & $0.58 * * *$ & & & & \\
\hline Yld16 & $0.12 \mathrm{~ns}$ & $0.24 *$ & $0.16 \mathrm{~ns}$ & & & \\
\hline Yld17 & $0.35^{* *}$ & $0.48 * * *$ & $0.70 * * *$ & $0.27^{*}$ & & \\
\hline AYld & $0.40 * * *$ & $0.54 * * *$ & $0.84 * * *$ & $0.22 *$ & $0.93 * * *$ & \\
\hline CMYld & $0.41 * * *$ & $0.57 * * *$ & $0.87 * * *$ & $0.29 * * *$ & $0.94 * * *$ & $0.96^{* * *}$ \\
\hline
\end{tabular}

$* ; * * ; * * *$ ns - significance at $<0.05,<0.01,<0.001$ and not significant, respectively

TCSA = juvenile trunk cross-sectional area; Yld15 $=2015$ mean yield; Yld16 $=2016$ mean yield

Yld17 = 2017 mean yield; AYld = 2015 to 2017 mean yield; and CMYld = 2015 to 2017 cumulative yield

selected for large mean juvenile TCSA (Table 4). Similarly, there was a significant difference $(\mathrm{P}=0.008)$ for three-year mean yield based on mean juvenile TCSA with the yield of the set of genotypes with large mean juvenile TCSA being nearly twice that of the set of genotypes with small juvenile mean TCSA (Table 4).
The effect of selection for high yields based on mean juvenile number of laterals between 2013 and 2014 was also assessed with a t-test (Table 5). Except for 2016 yield, there were significant differences in yearly and cumulative yields $(\mathrm{P}=0.003)$ where the set of genotypes with greater mean juvenile number of laterals consistently out-yielded the set of genotypes 
TABLE 3. Variance components and genetic parameter estimates of vegetative and yield traits of 72 Robusta coffee clones evaluated for 6 years in New Tafo-Akim, Ghana

\begin{tabular}{lrrrrrr}
\hline Trait & \multicolumn{7}{c}{ Genetic parameter } \\
\cline { 2 - 7 } & \multicolumn{1}{c}{$\sigma^{2} \mathrm{~g}$} & \multicolumn{1}{c}{$\sigma^{2} \mathrm{e}$} & \multicolumn{1}{c}{$\mathrm{h}^{2}$} & $\sigma^{2} \mathrm{e} / \sigma^{2} \mathrm{~g}$ & $\mathrm{GCV}(\%)$ & PCV $(\%)$ \\
\hline TCSA $\left(\mathrm{cm}^{2}\right)$ & $9.09 \pm 1.76$ & $20.58 \pm 0.93$ & $0.31 \pm 0.09$ & 2.3 & 26.3 & 47.6 \\
Height $(\mathrm{m})$ & $0.04 \pm 0.01$ & $0.09 \pm 0.004$ & $0.32 \pm 0.12$ & 2.2 & 10.9 & 19.4 \\
No. of laterals & $53.30 \pm 11.20$ & $122.50 \pm 8.90$ & $0.30 \pm 0.05$ & 2.3 & 13.1 & 23.8 \\
Span $(\mathrm{m})$ & $0.02 \pm 0.01$ & $0.06 \pm 0.003$ & $0.25 \pm 0.06$ & 3.0 & 9.8 & 19.7 \\
Yld15 $\left(\mathrm{tha}^{-1}\right)$ & $0.33 \pm 0.07$ & $0.94 \pm 0.04$ & $0.26 \pm 0.06$ & 2.8 & 35.0 & 68.7 \\
Yld16 $\left(\mathrm{t} \mathrm{ha}^{-1}\right)$ & $0.07 \pm 0.02$ & $0.15 \pm 0.01$ & $0.30 \pm 0.09$ & 2.3 & 80.7 & 146.5 \\
Yld17 $\left(\mathrm{t} \mathrm{ha}^{-1}\right)$ & $0.89 \pm 0.18$ & $2.15 \pm 0.10$ & $0.29 \pm 0.08$ & 2.4 & 35.7 & 66.1 \\
AVY $\left(\mathrm{t} \mathrm{ha}^{-1} \mathrm{yr}^{-1}\right)$ & $0.33 \pm 0.06$ & $0.77 \pm 0.03$ & $0.30 \pm 0.09$ & 2.3 & 32.8 & 59.9 \\
CMY $\left(\mathrm{t} \mathrm{ha}^{-1}\right)$ & $2.35 \pm 0.45$ & $4.71 \pm 0.21$ & $0.33 \pm 0.11$ & 2.0 & 35.3 & 61.2 \\
\hline
\end{tabular}

TCSA = Juvenile trunk cross-sectional area. Yld15 = 2015 mean yield; Yld16=2016 mean yield; Yld17 $=2017$ mean yield; AYld $=2015$ to 2017 mean yield; CMYld $=2015$ to 2017 cumulative yield; $\sigma^{2} \mathrm{~g}=$ genotypic variance; $\sigma^{2} \mathrm{e}=$ error variance; $\mathrm{h}^{2}=$ broad-sense heritability; GCV = genotypic coefficient of variation; $\mathrm{PCV}=$ phenotypic coefficient of variation

TABLE 4. Clean coffee yield performance of 26 Robusta coffee genotypes based on selection for mean trunk cross-sectional area between 2013 and 2014

\begin{tabular}{lccccc}
\hline Trait & \multicolumn{2}{c}{ TCSA $\left(\mathrm{cm}^{2}\right)$} & & df & Probability \\
\cline { 2 - 4 } & $\begin{array}{c}\text { Large } \\
(\mathrm{n}=10)\end{array}$ & $\begin{array}{c}\text { Small } \\
(\mathrm{n}=16)\end{array}$ & & & \\
\hline 2015 mean yield $\left(\mathrm{t} \mathrm{ha}^{-1}\right)$ & 2.0 & 1.3 & 4.1 & 11.2 & 0.002 \\
2016 mean yield $\left(\mathrm{t} \mathrm{ha}^{-1}\right)$ & 0.4 & 0.3 & 0.6 & 24.0 & 0.529 \\
2017 mean yield $\left(\mathrm{t} \mathrm{ha}^{-1}\right)$ & 3.0 & 2.3 & 2.5 & 24.0 & 0.021 \\
2015 - 2017 mean yield $\left(\mathrm{t} \mathrm{ha}^{-1} \mathrm{yr}^{-1}\right)$ & 2.0 & 1.4 & 2.9 & 24.0 & 0.008 \\
2015 to 2017 cumulative yield $\left(\mathrm{t} \mathrm{ha}^{-1}\right)$ & 5.2 & 3.5 & 3.5 & 24.0 & 0.002 \\
\hline
\end{tabular}

TCSA = Mean juvenile trunk cross-sectional area between 2013 and 2014. Large class consisted of genotypes that were not significantly different from the genotype with the largest average trunk cross-sectional area between 2013 and 2014; small class comprised genotypes that were not significantly different from the genotype with the least trunk cross-sectional area between 2013 and 2014

with less mean juvenile number of laterals (Table 5).

\section{DISCUSSION}

This study was undertaken to explore the potential of using vegetative growth traits at the juvenile growth stage for selection earlier in a Robusta coffee breeding programme that would be as effective as selecting for yield in later years. The selection for yearly yields and cumulative yield, using mean TCSA and number of laterals at the juvenile stage, were to a large extent, effective in this study. Similar 
TABLE 5. Clean coffee yield performance of 20 Robusta coffee genotypes based on selection for mean number of laterals between 2013 and 2014 in a study to evaluate Robusta coffee in New TafoAkim, Ghana

\begin{tabular}{lccccc}
\hline Trait & \multicolumn{2}{c}{ No. of laterals } & $\mathrm{t}$ & $\mathrm{df}$ & Probability \\
\cline { 2 - 4 } & $\begin{array}{c}\text { More } \\
(\mathrm{n}=10)\end{array}$ & $\begin{array}{c}\text { Less } \\
(\mathrm{n}=10)\end{array}$ & & & \\
\hline
\end{tabular}

No. of laterals = Mean juvenile number of laterals between 2013 and 2014. The more class comprised the top 10 genotypes that were not significantly different from the genotype with the highest mean number of laterals between 2013 and 2014; the less class consisted of the bottom 10 genotypes that were not significantly different from the genotype with the least mean number of laterals between 2013 and 2014.

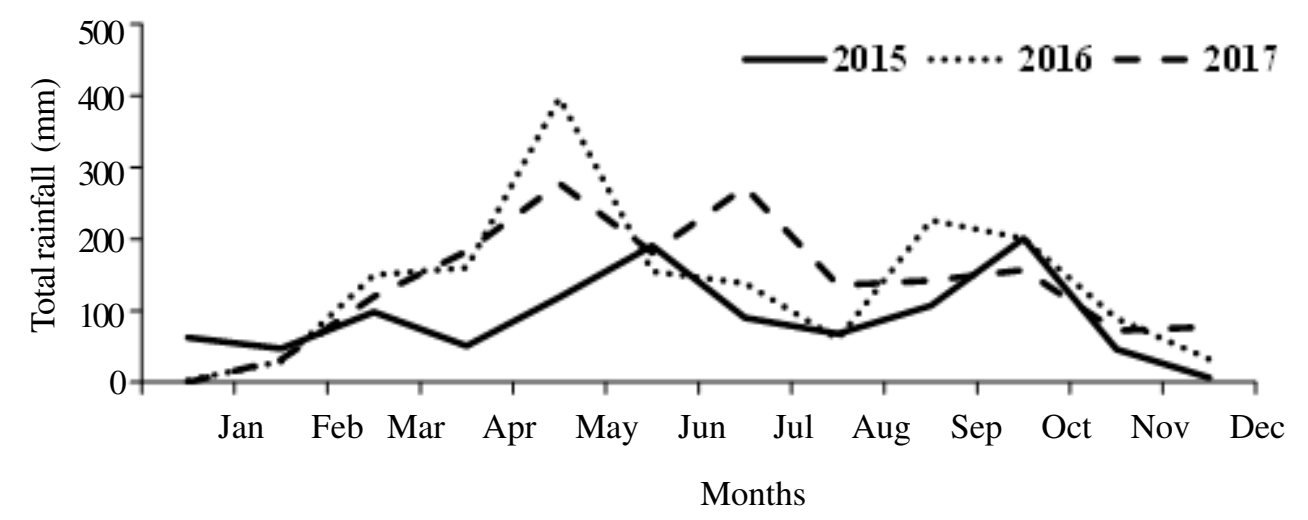

Figure 2. Monthly rainfall pattern from 2015 to 2017 for CRIG experimental station in New Tafo-Akim, Ghana.

to the findings in our study, Shaw and Hansen (1993) found that vegetative traits scored at the nursery stage could be used to improve yield in a strawberry breeding programme. Also, our findings concur with those of Souza et al. (2017), who showed that rubber yield was significantly correlated with traits related to vigour which could therefore, be used for indirect selection to shorten the breeding cycle. Also, similar observations were made in cocoa (Padi et al., 2012) and kola (Akpertey et al.,
2017), where varieties with poor juvenile phase growth rate were found to have poor yields.

In Robusta coffee, selection indices for vigour, moisture stress tolerance and yield using quantitative traits (stem diameter, number of laterals, span and height) have been shown to be successful (Walyaro and Van Der Vossen, 1979; Anim-Kwapong et al., 2011). In the present study, mean TCSA and number of laterals at the juvenile growth stage were 
positively and significantly correlated with yearly clean coffee yields (with the exception of 2016 yield) and cumulative yield. Additionally, there was a significant clean coffee yield (except for 2016) difference between the set of genotypes with large juvenile TCSA and small juvenile TCSA. Also, there was a significant clean coffee yield (except for 2016) difference between the set of genotypes that had more juvenile number of laterals and those that had less juvenile number of laterals.

This observation further emphasizes the reliability of juvenile growth traits in selecting high-yielding Robusta coffee genotypes in highyielding years, which may be the focus of most breeding programmes. Clean coffee yields in 2016 were consistently an exception in all the selection strategies employed in the present study. Clean coffee yields in 2016 were very low compared to yields in 2015 and 2017, for all the genotypes evaluated in the present study. This may have accounted for the lack of selection differences between the set of genotypes in the two classes of juvenile TCSA and number of laterals. Therefore, practicing selection in a low-yielding year like 2016 in our study may not be effective in identifying high-yielding genotypes. In all combinations of the juvenile vegetative traits studied as well as clean coffee yield, the correlations were positive and significant, with the exception of correlations between TCSA and 2016 clean coffee yield and number of laterals and 2016 clean coffee yield. This indicated that, with the exception of 2016 clean coffee yield, the selection for the improvement of one trait would cause positive gain in the other trait.

The biennial bearing (alternate bearing) nature where a high yield of the crop in one year was followed by low yield in the following year was evident in our study, irrespective of the yield produced by a particular genotype (Table 1 and Fig. 1). Dennis (2003) suggested this phenomenon to be a result of high yields in one year depleting the nutrients to form new fruit buds in the following year; although in apple, Jackson (2003) observed that seed- produced hormones exported from the developing ovules may have a direct inhibitory effect on flower development.

Optimum total rainfall and monthly distribution has been suggested by DaMatta $e t$ al. $(2006,2007)$ to affect coffee yields. Similarly, according to Rosenzweig et al. (2002), a heavy rainfall event and excessive soil moisture disrupt crop production, by causing reduced and staggered flowering, different berry growths, and difficulties in timing of operations like disease and pest management, lengthening the harvest and processing seasons, and compromising quality. Dean (1939) showed that the rainfall that is related to seasonal fluctuations in coffee, especially Arabica yield does not occur in the year of blossoming, maturing and harvesting; but rather the preceding year. In Robusta coffee, however, flowers and berries for that matter are formed on the current season's growth (DaMatta et al., 2007).

In the present study, it is difficult to attribute the rather low yields observed in 2016, to rainfall as there was optimum total rainfall in both $2015(1088.1 \mathrm{~mm})$ and 2016 (1642.9 $\mathrm{mm}$ ) and less fluctuation in rainfall between April and July of both years (Fig. 2) during the major rainy season in the Southern part of Ghana (CRIG, Tafo), where the experiment was conducted. Sub-optimal rainfall coupled with fluctuations during the major rainy season could affect flower and berry development, and overall yield at the end of the growing season. However, in the present study, despite the optimum rainfall obtained during the major rainy season as depicted in Figure 2, yields were very low in 2016. Other physiological and environmental factors such as photosynthetic intensity, temperature and relative humidity may have accounted for the low yields observed in 2016.

It is also possible that this is the genetic nature of the genotypes evaluated in the present study. Further studies, however, are needed in this regard to understand what causes such low yields in particular years. As the biennial bearing phenomenon observed in our study 
affected both high and low-yielding genotypes equally, selection of high-yielding genotypes in early production years, and advancing them in the breeding cycle would allow for reproduction of only specific genotypes that can be planted in larger populations to increase the proportion of desirable trees for hybrid and clone development.

Understanding the relationship between traits related to plant performance is advantageous in Robusta coffee breeding. Precocity, here defined as earliness to bearing (2015 yield) of Robusta coffee genotypes, showed a positive and high significant correlation with cumulative yield. The juvenile TCSA and number of laterals were both significantly and positively correlated with early yield (2015 yield) and cumulative yield. This indicates that genotypes that had high growth rate before bearing and high precocity, maintained yield superiority in later years; as such selection for cumulative yield could be effectively based on juvenile vegetative traits and early yields.

For all traits assessed in this study, the environmental (error) variance was higher than the genotypic variance that led to moderate heritability estimates (Table 3 ). The moderate heritability estimates, however, indicate the presence of additive genes in the expression of the traits and suggests moderate gains in Robusta coffee improvement through selection. In general, similar heritability estimates were observed for juvenile vegetative growth traits, and yield parameters in the present study. This, again indicate that selection for high-yielding Robusta coffee genotypes based on juvenile traits early in a breeding programme, would be as effective as selection in later years.

The observed similar heritability estimates (Table 3) and significant correlation between juvenile vegetative traits and yearly and cumulative clean coffee yields (Table 2) have a significant practical implication on improving Robusta coffee breeding programmes: most, if not all Robusta coffee breeding programmes, typically include testing of a large number of genotypes across many locations before making selection decisions, which comes with significant financial and land resource requirements. Therefore, pre-selection based on juvenile growth traits will reduce the potential number of genotypes to be tested in multi-location trials, resulting in a reduction in resource requirements at advanced stages of testing. Early identification of superior genotypes would undoubtedly allow only specific genotypes to be reproduced and planted in larger populations to increase the proportion of desirable trees for clone development (Soh et al., 2003) in a Robusta coffee breeding programme.

\section{CONCLUSION}

We examined the value of using juvenile TCSA and number of laterals as selection criteria for high-yielding genotypes among 72 Robusta coffee genotypes. Selection for juvenile TCSA results in gains in identifying genotypes with high yearly (except for 2016) and cumulative yields. Similarly, juvenile mean number of laterals is effective in predicting yearly (except for 2016) and cumulative yields of the Robusta coffee genotypes evaluated. Further studies are required to confirm the effectiveness or otherwise of using both juvenile traits (TCSA and number of laterals) in selecting for later years' yield in Robusta coffee given that there was no significant difference in 2016 clean coffee yield for the set of genotypes with large juvenile TCSA versus those with small juvenile TCSA, as well as no significant difference in 2016 clean coffee yield for the set of genotypes with more juvenile number of laterals versus those with less number of juvenile number of laterals. Exploiting the moderate positive significant correlations between juvenile vegetative traits and yearly yields and cumulative yield; early yield and cumulative yield; and selecting for large TCSA and high number of laterals early in a Robusta coffee 
breeding programme may result in moderate gains and improve the efficiency of selection.

Given the relatively low to moderate heritability estimates and correlation coefficients for associations between TCSA and number of laterals and yield found in this study, future research is necessary to confirm the possibility of using such juvenile traits to select for yield in Robusta coffee. A biennial yielding pattern was evident among the Robusta coffee genotypes evaluated in our study. A selection index that combines large juvenile TCSA and number of laterals would be advantageous in selecting productive and efficient genotypes in a Robusta coffee breeding programme.

\section{ACKNOWLEDGEMENT}

The authors are grateful for technical support of the staff of the Plant Breeding Division of CRIG, especially Mr. Lawrence Offei, Mrs. Gifty Amoako and Mrs. Diana Ohene-Asare in carrying out this research. The paper is published with the kind permission of the Executive Director, CRIG as manuscript number CRIG/09/2019/034/004.

\section{REFERENCES}

Adu, S.V. and Asiamah, R.D. 1992. Soils of the Ayensu-Densu basin (Memoir No. 9). Soil Research Institute/Council for Scientific and Industrial Research. Kumasi, Ghana.

Akpertey, A., Dadzie, A.M., Adu-Gyamfi, P.K.K., Ofori, A. and Padi, F.K. 2017. Effectiveness of juvenile traits as selection criteria for yield efficiency in kola. Scientia Horticulturae 216:264-271.

Anim-Kwapong, E. and Adomako, B. 2010. Genetic and environmental correlations between bean yield and agronomic traits in Coffea canephora. Journal of Plant Breeding and Crop Science 2:62-72.

Anim-Kwapong, E., Anim-Kwapong, G.J. and Adomako, B. 2011. Indirect versus direct selection of adaptable genotypes of Coffea canephora for drought stress and nonstress conditions. Journal of Crop Improvement 25:356-370.

Benjeddou, H., Ben Ahmed C., and Ben Rouina B. 2019. Influence of antioxidative enzymes, phytohormones and pigments in alternate bearing of three olive cultivars. Scientia Horticulturae 253:17-23.

Burton, G.W. 1952. Quantitative inheritance in grasses. Grassland Congress. Proceedings of the $6^{\text {th }}$ International Grassland Congress 1:227-283.

Coste, R. 1992. Coffee: The Plant and the Product. The Macmillan Press Ltd, London and Basingstoke, U.K. pp. 206-328.

DaMatta, F.M., Jose, D. and Cochicho, R. 2006. Impacts of drought and temperature stress on coffee physiology and production: a review. Brazilian Journal of Plant Physiology 18:55-81.

DaMatta, F.M., Ronchi, C.P., Maestri, M. and Barros, R.S. 2007. Ecophysiology of coffee growth and production. Brazilian Journal of Plant Physiology 19:485-510.

Davis, A.P. 2011. Psilanthus mannii, the type species of Psilanthus, transferred to Coffea. Nordic Journal of Botany 29:471472.

Dean, L.A. 1939. Relationship between rainfall and coffee yields in the Kona District, Hawaii. Journal of Agricultural Research 59:217-222.

Dennis, F. Jr. 2003. Flowering, pollination and fruit set and development. In: Apples: Botany, Production and Uses. D.C. Ferree and I.J. Warrington (Eds.), CABI Publishing, Cambridge, MA, pp. 153-166.

Falconer, D.S. 1998. Introduction to quantitative genetics. Ronald Press, New York, USA.

Jackson, J.E. 2003. Flowers and fruits. In: Biology of Apples and Pears. Cambridge University Press, New York, pp. 268-308.

Lachenaud, Ph. and Montagnon, C. 2002. Competition effects in cocoa (Theobroma 
cacao L.) hybrid trials. Euphytica 128:97104.

Lachenaud, Ph., Paulin, D., Ducamp, M. and Thevenin, J.M. 2007. Twenty years of agronomic evaluation of wild cocoa trees (Theobroma cacao L) from French Guiana. Scientia Horticulturae 113:313-321.

Mcartney S., Greene D., Schmidt T. and Yuan R. 2013. Naphthaleneacetic acid and ethephon are florigenic in the biennial apple cultivars Golden Delicious and York Imperial. HortScience 48:742-746.

Moreno-Alías, I., Rapoport, H.F., López, R., León, L. and de la Rosa, R. 2010. Optimizing early flowering and preselection for short juvenile period in olive seedlings. HortScience 45:519-522.

Ofori, A., Konlan, S., Dadzie, M.A. and Amoah, F.M. 2014. Genotypic performance of Cocoa (Theobroma cacao L.) during establishment under natural drought stress. Journal of Crop Improvement 28:804-824.

Padi, F.K., Opoku, S.Y., Adomako, B. and AduAmpomah, Y. 2012. Effectiveness of juvenile tree growth rate as an index for selecting high yielding cocoa progenies. Scientia Horticulturae 139:14-20.

Rosenzweig, C., Tubiello, F.N., Goldberg, R., Mills, E. and Bloomfield, J. 2002. Increased crop damage in the US from excess precipitation under climate change. Global Environmental Change 12:197202.
Sera, T. 2001. Coffee genetic breeding at IAPAR. Crop Breeding and Applied Biotechnology 1:179-200.

Shaw, D.V. and Hansen, J.J. 1993. The inheritance of vegetative growth traits in strawberries (Fragaria $\mathrm{x}$ ananassa) grown at low temperatures and their relationship to field productivity. Theoretical and Applied Genetics 87:170.

Soh, A.C., Gan, H.H., Wong, G., Hor, T.Y. and Tan, C.C. 2003. Estimates of within progeny genetic variability for clonal selection in oil palm. Euphytica 133:147163.

Souza, M.P., Queiroz, M.A., Possidio, E.L., Pereira, F.A. and Nunes, R.F.M. 2004. Study of flowering and alternate bearing of mango varieties in the São Francisco valley. ISHS Acta Horticulturae 645: VII International Mango Symposium. doi: 10.17660/ActaHortic.2004.645.43

Souza, A.M.D., Gouvêa, L.R.L., de Oliveira, A.L.B., Silva, G.A.P. and Gonçalves, P.S. 2017. Associations among rubber yield and secondary traits in juvenile rubber trees progeny. Euphytica 213:33.

Sposito M.B., Castro R.C. and Agusti M. 1998. Citrus alternate fruit bearing. Laranja 19:293-304.

Stewart, J.L. and Salazar, R. 1992. A review of measurement options for multipurpose trees. Agroforestry Systems 19:173-183.

Walyaro, D.J. and Van Der Vossen, H.A.M. 1979. Early determination of yield potential in Arabica coffee by applying index selection. Euphytica 28:465-472. 